\title{
筋電図計測を利用した和弓における発射技術の分析 ${ }^{\dagger}$
}

\author{
細 谷 聡* 岡田守彦** 宮 地 力*** \\ 大 山 圭 悟****
}

\section{Analysis of Release Technique of Japanese-style Bow by Using Electromyogram}

\author{
Satoshi HOSOYA*, Morihiko OKADA**, Chikara MIYAJI*** \\ and Keigo OHYAMA****
}

\begin{abstract}
Since the Japanese-style bow is very complicated in shape and structure, torques in horizontal and sagittal planes about the grip must be applied to hit the target. The purpose of this study was to investigate the relationship between left forearm muscle activities and torques in horizontal and sagittal planes about the grip. Surface EMGs of four muscles (extensor carpi radialis longus, extensor digitorum, extensor carpi ulnaris,flexor carpi ulnaris) and torques were collected for ten male subjects shooting arrows. Crosstalks between EMGs obtained from adjacent recording muscles were evaluated by using cross-correlation function. Absolute values of less than 0.3 of cross-correlation coefficient were considered as a criterion for specific EMG signals. As a result of statistic analysis. Extensor digitorum and extensor carpi ulnaris muscles had positive relationships to the torque in the horizontal plane. On the other hand, extensor carpi ulnaris, flexor carpi ulnaris and flexor carpi ulnaris muscles had positive relationships to the torque in the sagittal plane. It is found that extensor carpi ulnaris is a bifunctional muscle in release technique (TENOUCHI) of Japanese-style bow.
\end{abstract}

Key words : Electromyogram, Crosstalk, Japanese-style Bow, TENOUCHI

†原稿受付 2001年10月26日

*信州大学纎維学部

下386-8567 長野県上田市常田 3-15- 1

**筑波大学

于305-8574 茨城県つくば市天王台 $1-1-1$

***国立スポーツ科学センター

テ115-0056 東京都北区西が丘 3-15-1

****筑波大学体育科学系

テ305-8574 茨城県つくば市天王台 $1-1-1$

*Shinshu University, Faculty of Textile Science and Technology, 3-15-1, Tokida, Ueda, Nagano, Japan(3868567)

** University of Tsukuba, 1-1-1, Tennodai, Tsukuba, Ibaraki, Japan (305-8574)

***Japan Institute of Sports Science, 3-15-1, Nishigaoka, Kita, Tokyo, Japan(115-0056)

****University of Tsukuba, Health Physical Education and Sports Sciences, 1-1-1, Tennodai, Tsukuba, Ibaraki, Japan (305-8574) 


\section{1.はじめに}

筋電図計測は，医療分野やリハビリ分野，体 育・スポーツ分野等において，筋の機能解析や 運動機能解析, 動作解析を目的に広く利用され ている計測技術である。その中でも表面筋電図 法は, 皮膚表面上に電極を貼付すれば装着部皮 下の筋収縮情報が得られるという計測の簡便さ から, 最も一般的である。 スポーツ指導やスポ 一ツ工学分野においても筋電困計測は, 身体動 作や技術の解析 ${ }^{12)}$, 筋活動量からの関節角度や 関節トルク, 発揮パワーの推定などを行なう場 合 ${ }^{374) 5}$, 有効な解析手法の一つといえる. 筋電図 による弓射動作の研究は, いくつか行われてい るが, 弓射動作の開始から終了まで概括的に扱 っており，発射技術に焦点をあてた研究は見当 たらない6)7.
本稿の対象となる和弓の発射現象は, 弦が射 手の右手から離れて弦と矢が分離するまでが約 100 分の 3 秒という，ごく短い時間で終始する. さらに, 弓幹と矢の位置関係や握り部の位置な どの構造上の理由から, 矢を単に射放せば狙っ た地点よりも右上方へ逸れるという特徵である. 従って, この現象を補正するため発射の瞬間に 弓幹の長軸周りにはねじりモーメントを, さら には弓幹の上部を的の方へ倒すような力のモー メントを同時に加えるという発射技術が要求さ れるのである(図1)。発射の瞬間にこのような 力のモーメントを加えることを, 弓道の指導書 では「手の内」あるいは「手の内の働き」と称 して非常に重要視している.

発射の瞬間, 握り部に作用する力のモーメン トの原動力は左上肢の筋活動である.ごく短い 復元時間中に力のモーメントを作用させるため

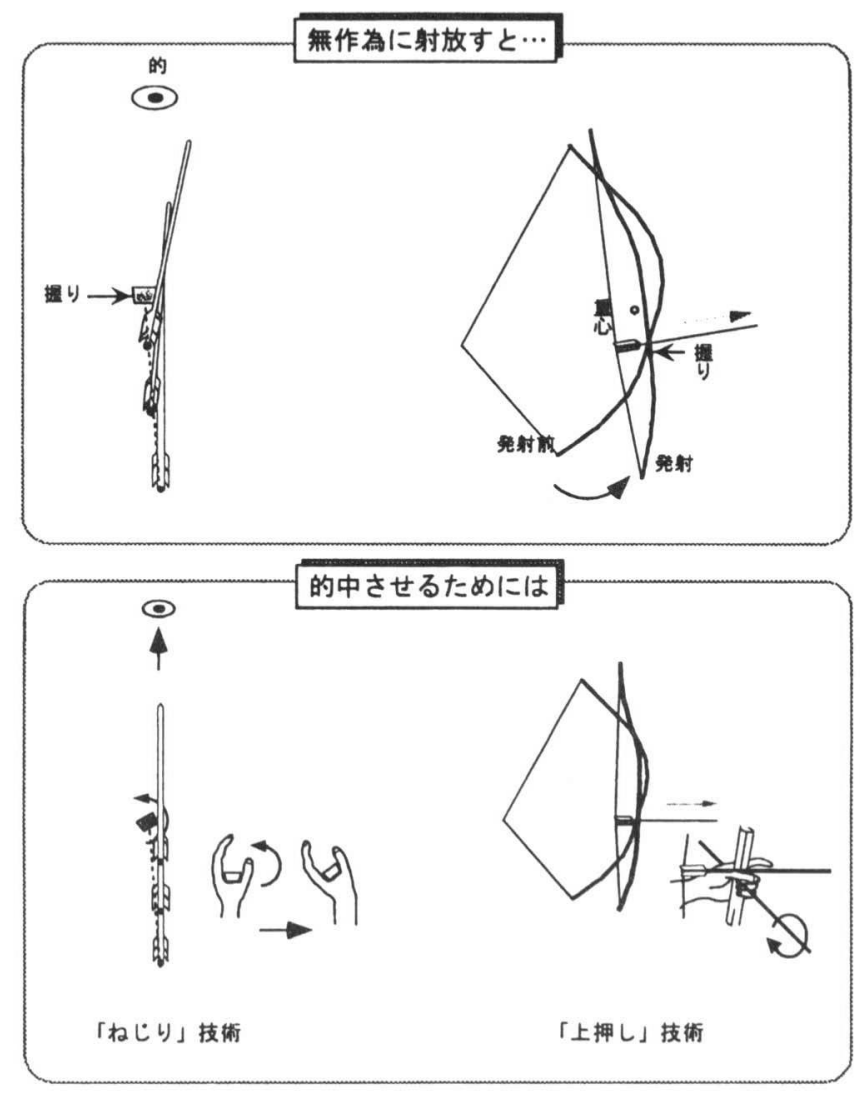

図 1 和弓の発射技術「手の内」 
には，発射の準備期から連続的な制御がなされ ていることが考えられる。従って，筋活動にも 動作に対応した変化が生じる可能性が高い.こ のような技術の分析には，表面筋困法による計 測が非常に適していると考えられる。しかしな がら, ヒトの上肢には複数の表在筋が入り組ん でおり，表面電極で目的の筋活動を計測する場 合, 近接する筋の収縮情報 (活動電位) が混入 する可能性がある。これは, クロストークと呼 ばれる現象で，表面筋電困計測では注意しなけ ればならないことの一つである。

本研究では, 弓幹に対して力のモーメントを 作用させるのに重要な役割を果たす左前腕の筋 活動について表面筋電困を用いて分析していく. ここでの目的は，計測時にクロストークをチェ ックする方法を導入し, 左前腕の筋群の活動と 「手の内の働き」との関係を明らかにすること である。

\section{2. 方法}

\section{1 被験者}

被験者は日置流印西派弓術を学ぶ健康な男性 10名とした。被験者の経験年数は 1 ～25年で, 普段の的中率は65～80\%である. 被験者の特徵 を表 1 に示す.

\section{2 実験装置}

2.2. 1 実験弓と力のモーメントの計測 実験には, 被験者が普段稽古で使っている弓

表 1 被験者

\begin{tabular}{ccccc}
\hline 被験者 & 年令 & 経験年数 & 的中率 & 普段の使用弓 \\
\hline 1 & 19 & 8 & $80 \%$ & $209 \mathrm{~N} / \mathrm{m}$ \\
2 & 21 & 9 & $80 \%$ & $261 \mathrm{~N} / \mathrm{m}$ \\
3 & 20 & 5 & $80 \%$ & $222 \mathrm{~N} / \mathrm{m}$ \\
4 & 19 & 4 & $80 \%$ & $209 \mathrm{~N} / \mathrm{m}$ \\
5 & 22 & 6 & $70 \%$ & $216 \mathrm{~N} / \mathrm{m}$ \\
6 & 20 & 8 & $60 \%$ & $189 \mathrm{~N} / \mathrm{m}$ \\
7 & 19 & 1 & $70 \%$ & $196 \mathrm{~N} / \mathrm{m}$ \\
8 & 21 & 7 & $60 \%$ & $196 \mathrm{~N} / \mathrm{m}$ \\
9 & 19 & 3 & $65 \%$ & $196 \mathrm{~N} / \mathrm{m}$ \\
10 & 46 & 25 & $75 \%$ & $209 \mathrm{~N} / \mathrm{m}$ \\
\hline
\end{tabular}

と強さ $183 \mathrm{~N} / \mathrm{m}$ のカーボンファイバー製弓の 2 張を使用した。「手の内の働き」によって弓幹に 作用する力のモーメント等を計測するため, 後 者の実験弓にのみ弓幹の握り部付近の前面と背 面にひずみゲージを接着した。計測項目は長軸 まわりに作用するねじりモーメント, 弓幹の上 部を的側に倒すようにして作用させる力のモー メント (以後上押しモーメントとする), 弓幹の 曲がり具合（以後曲げとする）の 3 つである。 解析において復元時間中（弦が右手より離れて から矢と弦が分離するまでの時間）の力のモー メントの積分値を算出するために, 右手の弦を 保持する部分に電極をつけ発射の信号を検出し た。また，弦を弓に張った初期状態付近で弦と 矢は分離することが報告されていることから ${ }^{8)}$, 弓幹が初期状態まで復元した時期は曲げ信号に よって判断した.

2.2.2 被験筋と表面筋電困の計測

左前腕の筋活動を調べるために，長橈側手根 伸筋, 指伸筋, 尺側手根伸筋, 尺側手根屈筋の 4 つの筋を被験筋とした (図 2 )。表面筋電困は 導出部の直径が $2 \mathrm{~mm}$ 表面電極を用い表面双極 導出法にて計測した。電極の中心から中心まで の距離を約 $1 \mathrm{~cm} し て ，$ 各筋の筋腹中央部に両 面粘着力ラーによって貼付した，皮膚抵抗を減 らし粘着をよくするために, 電極の貼付に先立 ちエチルアルコールによる脱脂と消毒を行ない, 電極中央部に対応する表皮 (角質層) のごく一 部を針によって剥離した。検出した発射準備期

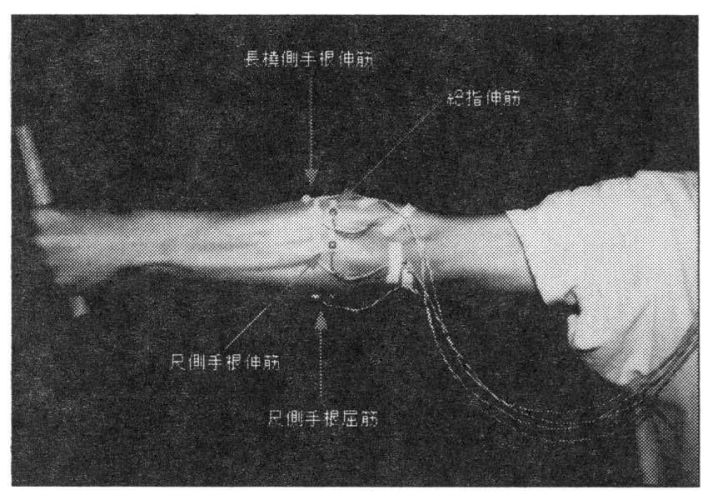

図 2 筋電困計測した前腕の筋群 
から発射時の筋電位はマルチテレメータシステ ムを介してカのモーメント信号と合わせてデー タレコーダに記録した。

\section{3 実験試技}

実験室内に設置した巻㩰を標的として，2 張 の弓についてそれぞれ10射ずつの発射実験を行 なった．実験の概要を図 3 に示す．各被験者の 筋電位信号の規格化とクロストークのチェック を行なうため, 各被験者には発射実験後に徒手 筋力測定法によって左手関節の背屈および尺側 偏位 (尺屈)の最大随意収縮 (Maximum Voluntary Contraction；MVC) を約 3 秒間ずつ行な ってもらい，筋電位信号を記録した。「手の内の 働き」は先にも述べたようにるねじりモーメン トと上押しモーメントで記述することができる. このねじりモーメントを作用させるとき, 左手 関節は結果として背屈位をとる。また，上押し モーメントを作用させ用とすれば，左手関節は 尺側偏位をとることから，このような解剖学的 な姿勢で最大随意収縮（MVC）を計測した。

\section{4 データ処理}

データレコーダに記録されたデータは，A/D 変換しパーソナルコンピュータで解析した. 力 のモーメント信号のサンプリングタイムは $0.1 \mathrm{~ms}$ $(10 \mathrm{KHz})$ ，筋電位信号の場合は $0.5 \mathrm{~ms}(2$ $\mathrm{KHz})$ とした.

「手の内の働き」を定量化するため，弓に作 用したねじりモーメントおよび上押しモーメン

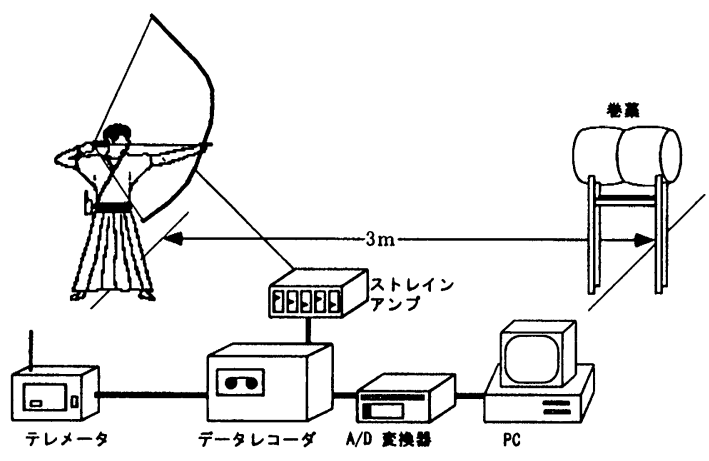

図 3 実験構成図
トについて復元時間中の積分值を算出した.

クロストークは，隣接する筋の電位信号の類 似性を相互相関関数によって評価することにし た。つまり，ある時点での相互相関係数が高け れば筋電位信号に類似性がありクロストークの 可能性が高いということになる，相互相関関数 は次式で与えられる。

$$
R_{x y}(\tau)=\frac{1}{T} \int_{0}^{T} x(t) y(t+\tau) d t
$$

$\mathrm{x}(\mathrm{t}), \mathrm{y}(\mathrm{t})$ : 隣接する筋の電位信号

$\mathrm{T}:$ デー夕の時間的長さ

$\tau$ ：ずらし時間 $(0 \leqq \tau \leqq T)$

また，相互相関関数を一 1 から +1 にするため の規格化は次のとおりである。

$$
R_{x y}^{\prime}(\tau)=\frac{R_{x y}(\tau)}{\sqrt{R_{x x}(0) R_{y y}(0)}}
$$

$\operatorname{Rxx}(0): \tau=0$ における $\mathrm{x}(\mathrm{t})$ の自己相関 $\operatorname{Ryy}(0): \tau=0$ におけるy $(\mathrm{t})$ の自己相関 相互相関関数を用いたクロストークの評価に ついてVink ら ${ }^{9}$ は，筋電位信号における相互相 関係数の負の值は合理的な説明がないと報告し ている。しかし，運動神経から筋にパルスが伝 えられた後，活動電位は神経と筋接合部を挟ん で对照的な伝播パターンをとり，接合部を挟ん だ場合の筋電位波形は同型で逆相となることが わかっており ${ }^{10)}$ ，波形の類似具合を示す相互相関 係数が負の值をとることは十分考えられる。ま た一方で, Winter ら ${ }^{11)}$ は相互相関関数によるク ロストークの評価を正の值で行なっているが, 本研究においては正負両方の可能性を考慮して 相互相関係数の絶対值をとり，その中の最大值 で評価することにした。ここで最大値を評価に 用いるのは，クロストークの可能性に関する上 限を示すためである。なお，相互相関関数の算 出には 2 秒間の最大随意収縮時のデー夕を使用 した，発射準備期から発射時の筋電位信号は整 流した後に単位時間あたりの積分値を求め，最 大随意収縮時における単位時間あたりの積分值 を100\%として規格化し被験筋の活動の大きさを 表わすことにした（以後\% MVCとする). 


\section{3. 結果および考察}

\section{3 . 1 表面筋電位信号のクロストークについ} $\tau$

徒手筋力測定によって計測した最大随意収縮 時における隣接する筋の電位信号の一例を図 4 に，また各被験者における相互相関関数の最大 值の平均を表 2 に示す，背屈試技では主に長橈 側手根伸筋，指伸筋，尺側手根伸筋が活動して おり，尺属試技では指伸筋，尺側手根伸筋，尺 側手根屈筋が主として活動していることがわか る。ほとんどの組み合わせにおいて，相互相関 関数の最大值の平均が 0.3 より 小さい值を示して いる.

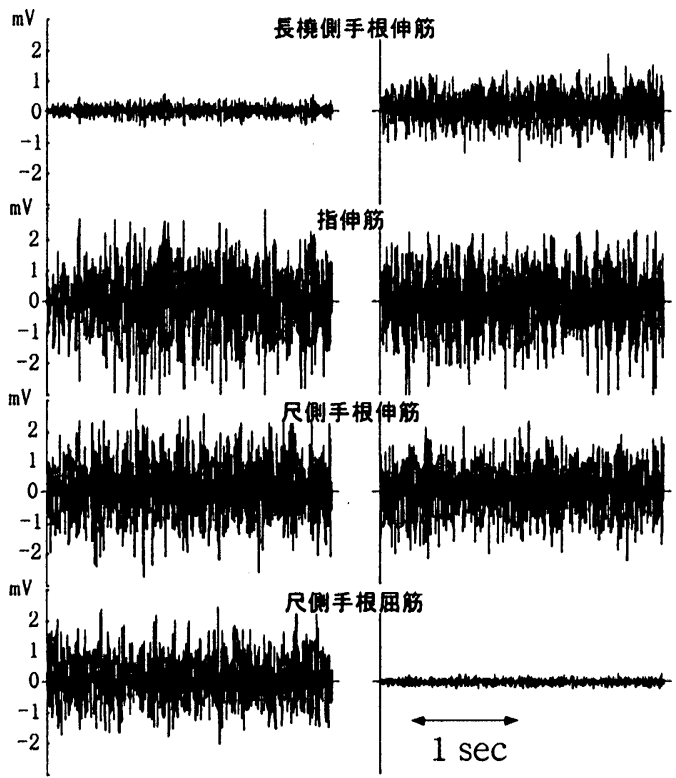

図4 従手筋力測定による最大随意収縮時の筋活動 （被験者 1)

右列：背屈試技，左列：尺屈試技
Vink ら ${ }^{9)}$ は腰部の筋に関するクロストークの 研究で，2つの計測部位の距離を $3 \mathrm{~cm}$ 以上離し て配置すると相互相関係数は 0.3 を回ることを 示し，0 0.3の範囲であれば検出される筋電位 信号は十分信頼できると結論づけている。これ に関連した研究では, Winter ら ${ }^{11}$ が 2 つ信号 源を設定した理論モデルを用いて，2つの計測 箇所の距離を変化させクロストークの影響を計 算した結果, 距離 $2 \mathrm{~cm}$ でクロストークが13\%, 距離 $3 \mathrm{~cm}$ で 4 \%になると報告している。これら のことから，隣接する計測部位の距離が $3 \mathrm{~cm}$ 以 上の場合はクロストークの影響を考慮しなくて も問題ないと考之られるが，今回の場合のよう に $3 \mathrm{~cm}$ 未満になるときはクロストークについて 相互相関関数を用いるなどしてチェックするこ とが重要だと考えられる。

今回の計測では，尺屈試技における長橈側手 根伸筋と指伸筋間において相互相関係数が $0.39 \pm 0.23$ (平均值 \pm S.D.) という比較的高い值 を示した(表 2 )。これは，長橈側手根伸筋の活 動電位レベルが指伸筋に比べて著しく低いため, 指伸筋から不可避的な信号の混入が相対的に多 く反映され，筋電位信号の類似性が高まったも のと推察される．同じような状況が背屈試技に おける尺側手根伸筋と尺側手根屈筋との間にも

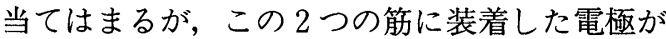
$3 \mathrm{~cm}$ 以上離れているため信号の混入がほとんど なく，結果として相互相関係数が比較的小さな 值だったと考えられる。

表 2 に示したこの他の組合せでは，相互相関 係数が0.3末満になっている.図 4 に示す各筋の 活動をみると，背屈試技における尺側手根屈筋 の活動を除き，個々の筋の活動レベルが高いこ とがわかる，従って，表在筋が多く複雑に入り

表 2 隣接する筋の相互相関係数

\begin{tabular}{cccc}
\hline & $\begin{array}{l}\text { 長橈側手根伸筋 } \\
\text { 一指伸筋 }\end{array}$ & $\begin{array}{l}\text { 指伸筋一 } \\
\text { 尺側手根伸筋 }\end{array}$ & $\begin{array}{c}\text { 尺側手根伸筋 } \\
\text { 一尺側手根屈筋 }\end{array}$ \\
\hline 背屈試技 & $0.22 \pm 0.09$ & $0.16 \pm 0.04$ & $0.19 \pm 0.08$ \\
尺屈試技 & $0.39 \pm 0.23$ & $0.21 \pm 0.11$ & $0.11 \pm 0.01$ \\
\hline
\end{tabular}


組んでいる前腕で計測部位の距離が $3 \mathrm{~cm}$ 未満と なる場合でも，表面電極によって検出する活動 電位レベルが隣接する筋で互いに高ければ，ク ロストークの影響はほとんどないことも示唆さ れた.

以上のことから, 計測部位の距離が $3 \mathrm{~cm}$ 未満 の場合や, 隣接する筋の活動電位レベルが著し く異なる場合（一方の活動が高く，他方が低い 場合）には，クロストークの影響をある程度考 慮しなければならない.しかし, 計測部位の距 離が $3 \mathrm{~cm}$ 末満の場合でも検出される活動電位レ ベルが相互に高ければ，クロストークの可能性 は低いと考之られる。次節以降で示すように本 稿では着目する運動に応じた筋の活動レベルは 比較的高いことから, 計測部位の距離が $3 \mathrm{~cm}$ 未 満であってもクロストークの影響は実験結果の 解釈に影響をおよばさないと判断した。

筋電図計測におけるクロストークは，考慮さ れなければならない重要な問題の一つである。

特に, 計測部位の距離が $3 \mathrm{~cm}$ 未満となるような 近接する筋を対象に表面筋電図を計測する場合 には，相互相関関数などを導入することによっ てチェックすることが重要だと考えられる，表 面筋電図を利用する各分野でも計測時に留意さ れるべきであり，筋電図計測の結果を有効に活 用するためにも必要である。

\section{2 発射前における左前腕の筋活動の特徵 について}

図 5 は，発射前 0.5 秒間の活動量を各筋の \% MVC で示した一例である.被験筋の中では尺側 手根伸筋の\% MVCが高い傾向は，すべての被 験者で共通であった．また，引張力が弱い弓に なると各筋の\% MVCは一様に低くなるが，長 橈側手根伸筋と尺側手根屈筋の減少の割合より も指伸筋と尺側手根伸筋の減少の割合の方が顕 著なことも各被験者において認められた。 3 。

1 で長橈側手根伸筋と指伸筋間のクロストーク の影響を考慮すべき場合があることを示したが， 筋活動の減少の割合が異なることから活動量に 対するクロストークの影響は無視できると考え られる。

また,この引張力の強い弓から弱い弓になる と指伸筋と尺側手根伸筋の活動が比較的顕著に 減少することは，これらの筋がねじりモーメン 卜と関係していることから引張力が小さくなる ことよりも弓幹のねじり剛性が弱くなることよ る影響が大きいのではないかと考えられる。

次に図 6 は, 発射直前における左前腕の筋活 動の一例である，長橈側手根伸筋，指伸筋，尺 側手根伸筋の 3 つと尺側手根屈筋とでは活動の 様相が異なり，この 3 つの伸筋においては発射 の直前に活動（波形の振幅）が増加していくが, 尺側手根屈筋では減少していくことが読み取れ

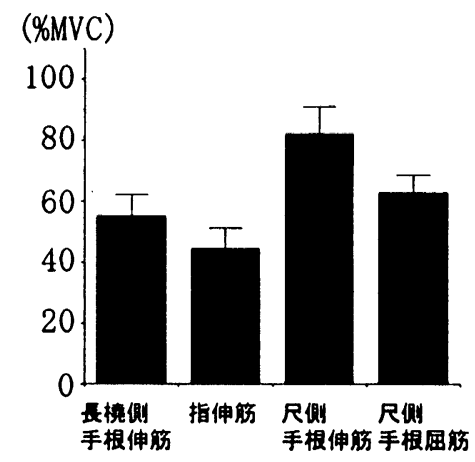

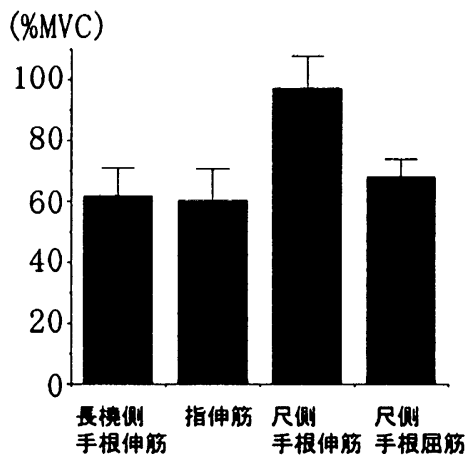

図 5 発射前0.5秒間における各筋の\% MVC（被験者10） 左：普段使っている弓 $(209 \mathrm{~N} / \mathrm{m})$ 右：実験で用意した弓 $(183 \mathrm{~N} / \mathrm{m})$ 
る.この傾向は，ほとんどの被験者で認められ た. そこで，この発射直前の活動を定量化しよ $\eta$ 詳細に調べるため, 発射前 0.5 秒間を 0.1 秒間 ごとに分割して各区間の\% MVCを表わした一 例が図 7 である．特徵的な点としては，長橈側 手根伸筋, 指伸筋, 尺側手根伸筋では発射直前 の0.1 0.2秒間に筋活動が顕著に増大していく のに対して，尺側手根屈筋では逆に顕著に減少

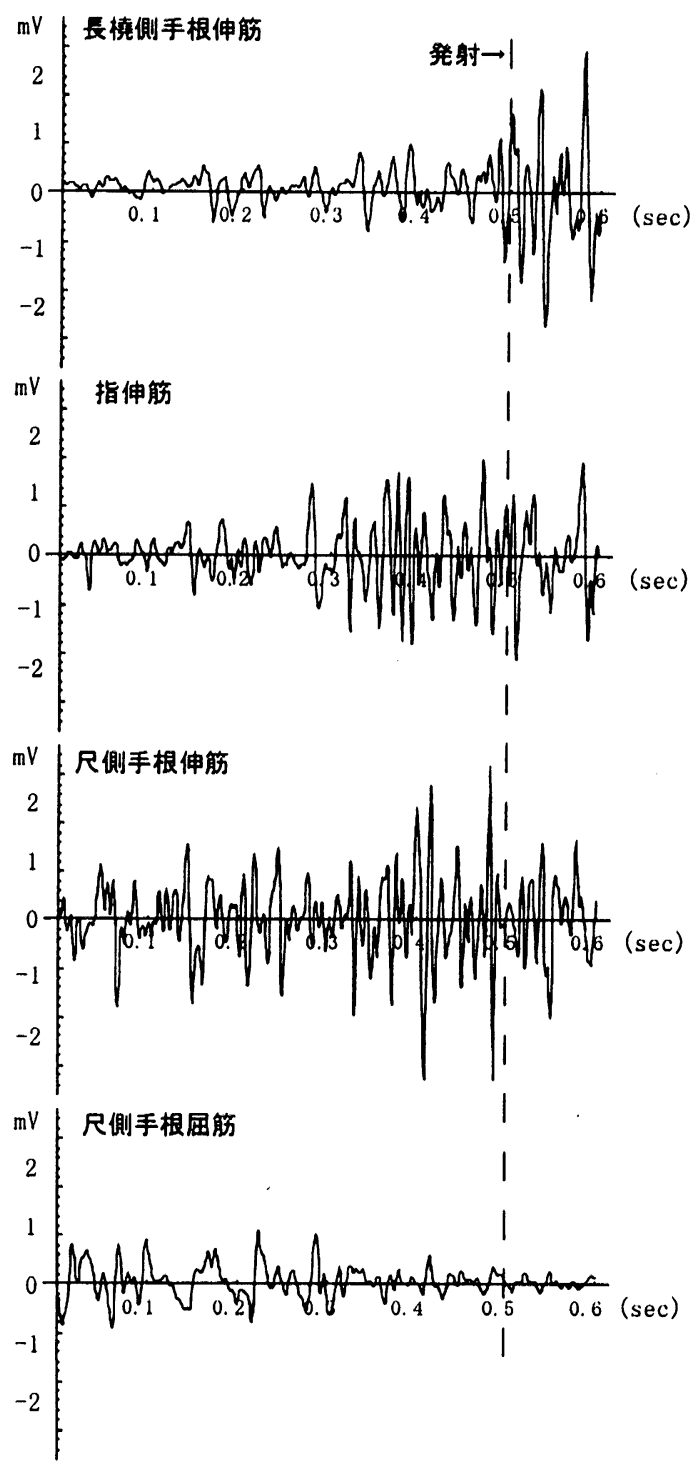

図 6 発射前後の各筋の表面筋電位の一例 （被験者10）
していることである。この現象は，ほとんどの 被験者において確認された。こらのことから， 左前腕の筋活動は目的の動作を遂行するために, 選択的に制御されていることが明らかとなった。

\section{3 発射前の筋活動と「手の内の働き」の 関係について}

左前腕の筋活動と復元時間中の弓幹に作用す るねじりモーメントおよび上押しモーメントと の関係を調べるために, 発射前の各筋の\% MVC と各モーメントの積分值について相関係数を求 めた.ここで発射前の筋の\% MVC を取り上げ たのは，表面筋電図に現われる筋活動は結果と して生じる筋張力よりも早い時点で認められる からである。

表 3 は発射前0.5秒間の\% MVC と復元時間 中のねじりモーメントの力積值の相関係数を示 したものである。ねじりモーメントの増大に関 わっているのは指伸筋と尺側手根伸筋であるこ とが明らかとなった．また，尺側手根屈筋の活 動が減少するとねじりモーメントが増加する傾 向があることもわかった。このことから主働筋

$$
\begin{aligned}
& 1: 0.5 \text { 秒前 } ~ 0.4 \text { 秒前 } \\
& 2: 0.4 \text { 秒前 } 0.3 \text { 秒前 } \\
& 3: 0.3 \text { 秒前 } 0.3 \text { 秒前 } \\
& 4: 0.2 \text { 秒前 } 0.1 \text { 秒前 } \\
& 5: 0.1 \text { 秒前 } \sim \text { 発射 } \\
& 6: \text { 発射 } \sim 0.1 \text { 秒後 }
\end{aligned}
$$
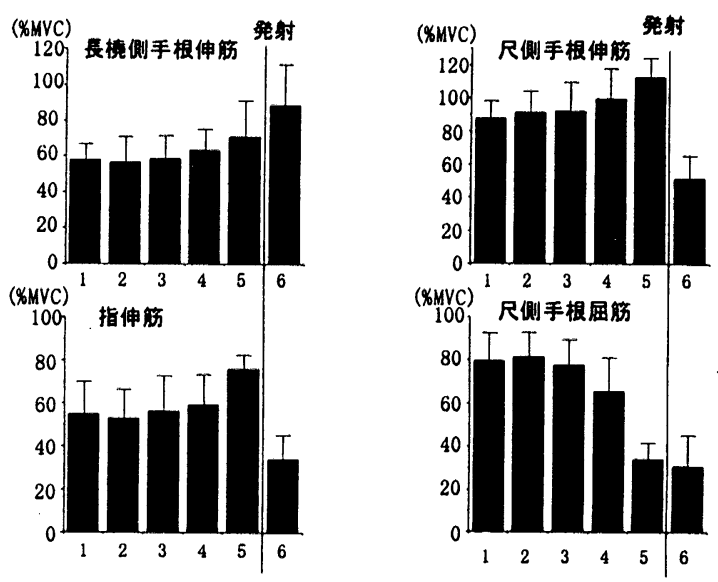

図 7 発射前0.1病区間ごとの各筋の\% $\mathrm{MVC}$ (被験者10) 
衰 3 発射前 0.5 秒間の筋活動と復元時間中のねじりモーメントの力積の相関

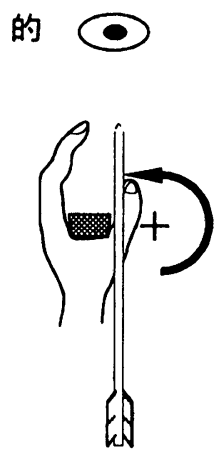

総和 $=$ 局面 $1+$ 局面 $2+$ 局面 $3+$ 局面 $4+$ 局面 5

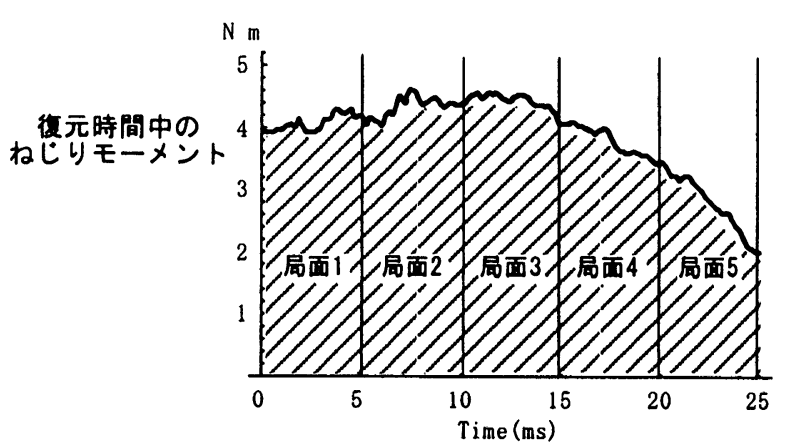

\begin{tabular}{ccccccc}
\hline & 総和 & 局面 1 & 局面 2 & 局面 3 & 局面 4 & \multicolumn{1}{c}{ 局面 5} \\
\hline 長橈側手根伸筋 & -0.07 & -0.12 & -0.19 & -0.15 & -0.03 & $0.24^{*}$ \\
指伸筋 & $0.44^{* * *}$ & $0.30^{* *}$ & $0.27^{* *}$ & $0.35^{* *}$ & $0.54^{* * *}$ & $0.70^{* * *}$ \\
尺側手根伸筋 & $0.35^{* *}$ & $0.26^{* *}$ & $0.25^{* *}$ & $0.31^{* *}$ & $0.44^{* * *}$ & $0.44^{* * *}$ \\
尺側手根屈筋 & $-0.29^{* *}$ & -0.13 & -0.15 & $-0.24^{*}$ & $-0.38^{* * *}$ & $-0.55^{* * *}$ \\
\hline & & & & & & ${ }^{*} \mathrm{p}<0.05$ \\
& & & & & & $* * \mathrm{p}<0.01$ \\
& & & & & & \\
& & & & & &
\end{tabular}

表 4 発射前 0.5 秒間の筋活動と復元時間中の上押しモーメントの力積の相関

総和 $=$ 局面 $1+$ 局面 $2+$ 局面 $3+$ 局面 $4+$ 局面 5

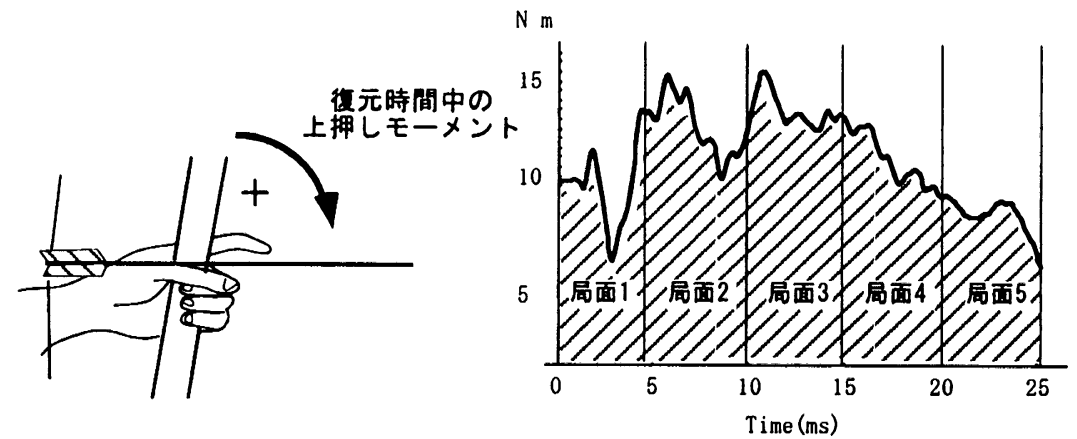

\begin{tabular}{ccccccc}
\hline & 総和 & 局面 1 & 局面 2 & 局面 3 & 局面 4 & 局面 5 \\
\hline 長橈側手根伸筋 & $-0.34^{* *}$ & $-0.34^{* * *}$ & $-0.31^{* *}$ & $-0.29^{* *}$ & $-0.35^{* *}$ & $-0.32^{* *}$ \\
指伸筋 & $-0.34^{* * *}$ & $-0.49^{* * *}$ & $-0.51^{* * *}$ & $-0.42^{* * *}$ & $-0.28^{* *}$ & 0.08 \\
尺側手根伸筋 & $0.35^{* *}$ & $0.43^{* * *}$ & $0.51^{* * *}$ & $0.43^{* * *}$ & $0.19^{* *}$ & 0.02 \\
尺側手根屈筋 & $0.26^{* *}$ & $0.35^{* *}$ & $0.39^{* * *}$ & $0.29^{* *}$ & 0.13 & 0.06 \\
\hline & & & & & & $* \mathrm{p}<0.05$ \\
& & & & & $* 0.01$ \\
& & & & & & $* 0.001$
\end{tabular}


の活動の増大と同時に拮抗作用のある筋の活動 の減少が起こり, 結果としてねじりモーメント が弓幹に作用するような動作を実現していると 考えられる。手関節の背屈に主に関わる筋は指 伸筋と尺側手根伸筋であることから，以上の結 果は解剖学的にも合致している. さらに, 指伸 筋と尺側手根伸筋の発射前の活動と復元時間終 盤のねじりモーメントの力積值とが比較的高い 正の相関を示している. 復元時間後半のねじり モーメントの力積值の増大は発射される矢の速

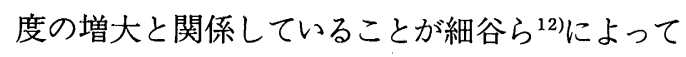
報告されている。このことから, 発射前の指伸 筋と尺側手根伸筋の使われ方は「手の内の働き」 を評価する上で一つの指標になると考えられる.

一方，表 4 の各筋の\% MVC と上押しモーメ ントとの関係をみると, 尺側手根伸筋と尺側手 根屈筋について正の相関を示し, 長橈側手根伸 筋と指伸筋では負の相関を示した。 尺側手根屈 筋の活動の促進と長橈側手根伸筋の活動の抑制 によって収縮力の差を生み出し上押しモーメン 卜に反映する力が発揮されていると推測される. また， 尺側手根伸筋の活動の増加はねじりモー メントの増加と関係するとともに，上押しモー メントの増加にも関係するという複合的な機能 を担っていると考えられる。ささらに，ねじりモ 一メントを増加させるために指伸筋の活動が増 加すると, 逆に上押しモーメントは減少すると いう对照的な関係があることが明らかになった。

\section{4.まと め}

本研究では, 和弓の発射技術である「手の内 の㗢き」に注目し, 弓幹へ作用させる力のモー メントの計測と左前腕の表面筋電困を用いて解 析した。計測された筋電困を解析するにあたっ て，クロストークをチェックする方法を導入し 筋電困の有効性を確認しながら, 左前腕の筋群 の活動と「手の内の働き」との関係ついて検討 した. 以下に結論を示す.

(1)計測部位の距離が $3 \mathrm{~cm}$ 未満の場合や, 隣接す る筋の活動電位レベルが著しく異なる場合（一 方の活動が高く，他方が低い場合）には，クロ
ストークの影響をある程度考虑しなければなら ない.しかし, 計測部位の距離が $3 \mathrm{~cm}$ 未満の場 合でも検出される活動電位レベルが相互に高け れば, クロストークの可能性は低いと考えられ る. 本研究では，筋活動量はそれぞれ比較的高 いことから，クロストークの影響は少なく実験 で得られたデー夕は実験結果の解釈に影響をお よぼさないと判断した。

(2)引張力が強い弓から弱いものになると各筋の \% MVC は一様に低くなるが，長橈側手根伸筋 と尺側手根屈筋における減少の割合よりも指伸 筋と尺側手根伸筋における減少の割合の方が顕 著に大きいことが認められた，また，発射直前 の0.1 0.2秒間に筋活動については，長橈側手 根伸筋，指伸筋，尺側手根伸筋では顕著に増大 していくのに対して，尺側手根屈筋では逆に顕 著に減少していた。このように, 左前腕の筋活 動は「手の内の働き」を遂行するために，選択 的に制御されていることが明らかとなった。

(3)「手の内の働き」のうち，ねじりモーメント の増大に関わっているのは，指伸筋と尺側手根 伸筋であることが明らかとなった。一方，上押 しモーメントに関わっているのは，尺側手根伸 筋と尺側手根屈筋であった，尺側手根伸筋の活 動の増加は, ねじりモーメントと上押しモーメ ントの増加に関係しており，複合的な機能を担 っていることが明らかとなった。

\section{参 考 文 献}

1) 川島一明；ゴルフのキネテックスな指導システムの 開発, J.J. Sports Sci., Vol.11，No.9，pp.524-535, 1992.

2 ）室增男，他；筋放電パターンからみた投球指導のポ イント, J.J. Sports Sci., Vol.11, No.9, pp.550$557,1992$.

3 ) 内山孝憲, 他; 静的な位置制御における関節角度・ 筋活動度・トルクの関係, 医用電子と生体工学, Vol. 34, pp.119-126, 1996.

4 ）内山孝憲, 赤澤堅造 ; 七上肘関節伸筋の筋活動度一 角度一等尺性トルク関係と一負荷トルクー速度関 係，バイオメカニズム14, pp.27-37, 1998. 
5 ）篠原稔, 他 ; 筋電困と発揮パワー, J.J. Sports Sci., Vol.11, No.3, pp.167-175, 1992.

6 ）亀井貞次 ; 弓 (和弓) の筋電図, J.J. Sports Sci., Vol.7, No.11, pp.727-730, 1988.

7 ）水野忠文, 他; 呼吸, 筋活動からみた弓道技術の研 究, 体育学研究, Vol.10, No.1, p.204, 1964.

8 ）稲垣源四郎；弓の技術 3 ,新体育, Vol.49, No.7, pp.636-643, 1979.

9 ) Vink, P., et. al. ; Specificity of surface-EMG on the intrinsic lumbar back muscles, Human Movement Science, Vol.8, pp.67-78, 1989.

10) Masuda, T. and Sadoyama, T. ; Skeletal muscle from which the propagation of motor unit action potentials is detectable with a surface electrode array: Electroenceph. Clin. Neurophysiol., Vol. 67, pp.421-427, 1987.

11) Winter, D., et. al. ; Crosstalk in surface electromyography: Theoretical and practical estimates, Journal of Electromyography and Kinesiology, Vol.4, No.1, pp.15-26, 1994.

12）細谷聡，他；和弓における手の内の「ねじり」技術 に関する力学的研究ーコンピュータシミュレーショ ンによる分析一, 武道学研究, Vol.26, No.3, pp. $31-40,1994$. 